\title{
Las «patrias» del soldado romano en el Alto Imperio
}

\author{
The "patriae" of the Roman soldier in the Empire
}

\author{
Sabino Perea Yébenes \\ Universidad de Murcia
}

\begin{abstract}
RESUMEN
El presente estudio es una reflexión sobre las patrias o formas de expresión de la patria de los soldados romanos en la epigrafía militar. Se tratan de definir la función «patronímica» que tienen conceptos jurídicos tan conocidos como natio, domus, origo, aplicadas a soldados en activo o veteranos. También se reflexiona sobre algunas formas artificiales de «patria» o pseudo-patrias en la vida del soldado, como puede ser la unidad militar "étnica», y los elementos de la vida militar como un universo propio: la vida del campamento, el culto imperial, o la lengua, que devienen en elementos comunes a todos los soldados que sirven lejos de su patria formando una «nueva nación": la que constituye el conjunto del elemento militar romano.
\end{abstract}

PALABRAS CLAVE:

Vida militar - Patria - Natio - Origo Domus - Onomástica - Epigrafía - Religión militar - Culto imperial - Lengua.

\begin{abstract}
This work is a reflection on the "mother lands" or forms of expression of the «mother land» of the Roman soldiers in the military epigraphy. They try to define the "patronymic» function that juridical concepts have so known like natio, domus, origo, applied to soldiers or veterans. Also one thinks about some artificial forms of pseudo-»mother lands» in the life of the soldier, since it can be the military "ethnic» unit, and the elements of the military world: the life of the camp, the imperial worship, or the language, which they develop into common elements to all the soldiers who serve far from her mother land forming a «new nation»: the one that constitutes the military universe.
\end{abstract}

KEYWORDS:

Military Life - "Mother Country" - Natio Origo - Domus - Onomastics - Epigraphy Military Religion - Imperial Cult - Languaje as Identity.

Esa gran maquinaria política que es el ejército romano es también un gran laboratorio de transformación de estatutos jurídicos y personales. La milicia tuvo una importancia extraordinaria en la carrera, militar y civil, de muchos hombres de la nobleza romana que en algún momento de su vida lucharon bajo algún estandar- 
te. La epigrafía relativa a los «caballeros» romanos, reunida desde hace años por el malogrado profesor Hubert Devijver ${ }^{1}$, muestra a las claras que el ejército no fue "sólo" un medio de promoción para los hombres del ordo equester, sino que fue «el medio» por excelencia en los tres primeros siglos del Imperio. Y si echamos una mirada sobre el «primer orden» social romano, el de los senadores, también vemos que el ejército fue el trampolín o la reválida para su carrera política de altos vuelos, e incluso el generalato en muchos notables, como sucede con la dinastía Flavia, para la que el ejército fue la antesala del trono de Roma ${ }^{2}$. Y, por supuesto, en el siglo III d.C., a partir del año 238, en el periodo denominado convencionalmente por la historiografía como «de la anarquía militar», raro era el emperador que no estaba avalado «únicamente» por las espadas de los soldados.

Para todo muchacho que viviese en cualquier punto del Imperio romano, fuera ciudadano de pleno derecho o no, el oficio de armas era una carrera «de las oportunidades": oportunidad para morir o sobrevivir, para ser premiado (con condecoraciones o con dinero) o ser castigado, para ser trasladado de provincia o de unidad, o gozar de privilegios internos, como el asociativo, der tipo profesional ${ }^{3}$. En esa diversidad de circunstancias posibles hay también una oportunidad para buscar la igualdad ante la ley, o un acercamiento de sus estatutos personales: por ejemplo conseguir los derechos y privilegios que otorga la ciudadanía romana a los hombres quienes no la tuvieran, o, una vez en el retiro, el reconocimiento de la comunidad cívica hacia el veterano que ha luchado por la defensa del imperio, y además gozar, en el orden práctico, de algunos privilegios jurídicos (como la exención de tutelas) ${ }^{4}$, laborales ${ }^{5}$, económicos (immunitates) $^{6}$, o penales ${ }^{7}$. Sólo esa gran institución que es el ejército romano hizo posible, como dijo el maestro H.-G. Pflaum $^{8}$, que todos los habitantes y todos los territorios del Imperio pudiesen vivir

1 H. Devijver, Prosopographia Militiarum Equestrium quae fuerunt ab Augusto ad Gallienum, Leuven 1977 ss. (Tres volúmenes principales y varios suplementos). Ver también, del mismo autor, los dos libros recopilatorios de sus principales trabajos de investigación: H. Devijver, The Equestrian Officers of the Roman Army, 2 vols. Amsterdam 1989 y 1992.

2 Sobe la importancia de la guerra en la carrera de los que serían los emperadores Vespasiano y Tito, ver mi trabajo: S. Perea Yébenes, «Tito César. Las vísperas de la púrpura», en el libro Res Gestae. Grandes generales romanos (I), Madrid 2004, 157-209.

3 S. Perea Yébenes, Collegia Militaria. Asociaciones militares en el Imperio Romano. Madrid 1999.

4 Cfr. Fragm. Vat. §140; §177; §195; etc.

5 Dig. 49, 18, 5 (Paul., de cognit.). «Antonino Magno <Caracalla>, de consagrada memoria, dijo en un rescripto dado juntamente con su padre que los veteranos tenían excusa respecto a la contribución de trabajar en la construcción de naves. (1) Y también tienen inmunidad para la cobranza de tributo, es decir, que no deben ser nombrados cobradores de tributos".

6 Dig. 49, 18, 2: «La inmunidad que se concede a los licenciados honrosamente del ejército vale también para las ciudades en que vivan como residentes, y no se extingue por el hecho de que acepten voluntariamente alguna magistratura o cargo. Los impuestos y contribuciones patrimoniales ordinarias deben pagarlos todos». (Ulp. 3 opin.). Cfr. C.B. Welles, «The immunitas of the Roman Legionaries in Egypt, » JRS 28, 1938, 41-49.

7 Dig. 49, 18, 1. El privilegio de los veteranos tiene relevancia, entre otras cosas también en materia de delitos, pues crea una distinción respecto a otras personas en el tipo de penas, ya que el veterano no puede ser condenado a la fieras ni apaleado. (Men. 3 de re milit.)

8 «Forces et faiblesses de l'armée romaine du Haut-Empire», en J.P. Brisson (ed.), Problèmes de la guerre à Rome, Paris 1969, 85-98 ( = «Fuerzas y flaquezas del ejército romano en el Alto Imperio», en 
en paz, a costa, naturalmente, del sacrificio y del oficio de los soldados y de sus oficiales. El ejército es verdaderamente una institución formada por un grupo humano grande al mismo tiempo heterogéneo y singular.

En el ejército, como en ninguna otra institución romana antigua, los conceptos de «extranjero» y de «intolerancia al elemento foráneo» se diluyen, hasta el punto de apreciar la variedad de pueblos y etnias que lo forman, no como un hecho negativo sino, al contrario, como un bien necesario, y diría yo que imprescindible. La inclusión de "extranjeros", no itálicos, en los ejércitos regulares de Roma desde comienzos del Principado es una medida inteligente más que demuestra el sentido práctico de los romanos. Así vemos que la maquinaria «conquistadora» romana, y también civilizadora, practica antes, dentro de su organización, el respeto al extranjero, lo valora y lo incorpora a su disciplina, eso sí, es verdad, en el lugar adecuado según su rango o rangos: primero según su rango estatutario y personal, y, ya en su unidad, de acuerdo con su oficio o especialidad táctica.

Son varios los elementos que quiero analizar someramente en relación con esta idea de «tolerancia al extranjero" que se tiene en el ejército romano. Todos ellos, por separado o combinados, actúan como lubricante que lima asperezas y diferencias culturales, hasta crear un verdadero sentido corporativo de «iguales», o casi iguales. Estos elementos actuaron como arietes (si se me permite una metáfora de tipo militar) capaces de derribar los muros de la intolerancia en las relaciones personales entre los soldados por razón de etnia. Me refiero concretamente, y en primer lugar, a la noción de patria o patrias que tenía o podía tener el soldado; y en segundo lugar (o segundo foco de atención) a una serie de hechos y circunstancias culturales e históricas que reforzaban el sentimiento de comunidad en el ejército altoimperial. Me refiero al campamento como "cosmópolis» (un «universo cívico»), con gentes de cualquier parte del mundo; a la indiscutible autoridad del el emperador como general en jefe de «todos» los soldados del Imperio y la creación y fortalecimiento de un culto a su persona, un culto no excluyente ni incompatible con otros, para todos los soldados; y finalmente a la aceptación de una misma lengua oficial para la vida castrense, el latín.

En las páginas que siguen el amable lector encontrará muchas ideas nuevas, que propongo para su debate a los estudiosos del ejército romano, y lo hago concientemente, con independencia de su fortuna o de su rechazo.

\section{LAS «PATRIAS»DEL SOLDADO ROMANO}

El ejército romano es la institución romana donde con mayor intensidad y número se acrisolan y funden etnias, culturas y nacionalidades. Los rasgos «patrios»

H.-G. Pflaum, El ejército romano y la administración imperial. Estudios de historia militar y prosopografía, Madrid 2003, 9-14).

9 Del mundo conquistado por Roma, obviamente. 
ceden ante la supra-organización militar que se presenta como una suma de nationes, de sistemas de combate, y de cuerpos de tropas distintos pero necesariamente complementarios. Por eso, y en relación con el hecho de «sentirse», o no, extranjero en el ejército romano, voy a dedicar una líneas a hablar de las posibles y distintas «patrias» del soldado.

En su justamente celebérrima obra sobre la legión III Augusta, el profesor Yann Le Bohec dedicó unas pocas líneas a «las patrias del soldado», tema que tiene un gran interés y puede ser desarrollado algo más. Viene a decir este estudioso que «un soldat romain pouvait estimer qui'il appartenait à plusieurs patries à la fois, sans qu'aucune exclût les autres» ${ }^{10}$. Pero ¿se trata únicamente de una realidad «emocional» o «afectiva», como sugiere la obra de M. Bonjuour ${ }^{11}$, de quien Le Bohec parece retomar la idea?, ¿o es una realidad jurídica?, ¿o no jurídica?

Le Bohec sintetiza que las patrias del soldado son tres: A) la patria geográfica, es decir, el lugar de nacimiento del soldado, en aquella población o provincia donde fue alumbrado. B) Una patria «lejana», es decir, allí donde el soldado presta su servicio. C) Una patria «jurídica», en aquellos casos en que el soldado ha adquirido recientemente la ciudadanía romana.

$Y$ añade, un poco a medias tintas, una cuarta patria, la «cultural», derivada de la «tercera» anterior, por cuanto, ya ciudadano romano, el soldado «il avait certainement été soumis à des influences diverses"... en aquella provincia donde su unidad tiene guarnición ${ }^{12}$.

Voy a matizar, si se me permite, esta sugerente clasificación, lanzando a la palestra del debate algunas reflexiones relativas al título este estudio, el estatuto personal y el sentido de «patria» para el soldado.

Naturalmente, en lo que podamos decir sobre «las patrias» del soldados debemos tener siempre presente la «alienabilidad» del documento, es decir, que la mención epigráfica de la natio, domus, u origo, se hace porque el documento epigráfico está lejos de tal natio, domus u origo del difunto. Afirma Ettore De Ruggero: «L'uso de la patria non era generale; ricorre nelle scrizioni relative ai soldati di ogni arma, cittadini e peregrini dimoranti e morti in luogo diverso da quello della loro origine. Mano a mano però l'uso si estede anche a persone non appartinenti all'essercito "13. De esta norma se apropia el colectivo de los gladiadores, en razón de su profesión itinerante, pero especialmente los soldados, precisamente por su movilidad: los militares sirven a Roma siempre lejos de su lugar de nacimiento.

\footnotetext{
10 Y. Le Bohec, La Troisième Légion, p. 494.

1 M. Bonjour, Terre natale. Études sur une composante affective du patriotisme romain, Paris 1975.

2 Y. Le Bohec, La Troisième Légion, p. 494.

13 E.De Ruggero, La patria nel diritto pubblico romano, Roma 1921, 28.
} 


\section{1.a) La natio, la domus}

Indudablemente, la primera patria en la vida del soldado es su natio, esto es, el lugar donde nace ${ }^{14}$. La natio, y la mención de la natio del soldado en las inscripciones, no tiene necesariamente un rango jurídico, sino únicamente geográfico. Alude a una ciudad, a una civitas, a un poblado, a un castrum (o castellum) o a un territorio ocupado por una gens autóctona de reconocida raigambre o prestigio lo suficiente para ser reconocida e identificada a muchos kilómetros de su ubicación. Con frecuencia tal natio coincide con una región sin límites bien precisos. Se trata más bien de una agrupación de núcleos dispersos de economía rural, que se constituyen como populus pero no como ciudad con un centro de gobierno e identidad política romana de pleno derecho. Tal marginalidad institucional política en un territorio sometido a Roma entrañaba dificultades prácticas en cuanto a la leva y a la administración de justicia. La actuación de los magistrados romanos enviados para tales menesteres en estas regiones era similar a la que tenía lugar en los municipios sine iure suffragio. Es posible que en las expresiones epigráficas alusivas a la natio del soldado aparezcan ambos parámetros (castrum/castellum o territorio + gens) cuando se quiere precisar al receptor de mensaje (por ejemplo un epitafio) la «cualidad» nacional del soldado difunto. Es el caso del famoso Pintaius Pedilici / f(ilius), Astur Trans/mo[n]tanus, castello / Intercatia, signifer / c(o)ho(rtis) $V$ Asturum...15.

En cierto modo equivalente a natio, el término o la mención a la domus también se refiere o se relaciona con el concepto de «clan», con la «casa» de la gens, su territorio o área de influencia. Precisa De Ruggero: «Tra l'esponente domo e natione passa questa differenza, che mentre con domo, seguito dal nome del comune, è sempre indicata l'appartenenza giuridica della persona ad esso, con natione invece si esprime il concetto del suo rapporto etnologico con la regione ${ }^{16}$.

No por ser el lugar de natio poco importante deja de mencionarse en la epigrafía funeraria. De hecho, mayor importancia que el rango o la lejanía del lugar de nacimiento tiene el hecho de que el soldado muera lejos de su patria. Pero, ¿por qué en los conjuntos epigráficos de un mismo yacimiento militar encontramos menciones a la natio u origo del soldado difunto y otras veces no? Indudablemente puede hablarse de una «moda epigráfica» (o más bien de aceptación y uso ge-

${ }^{14}$ El término natio nada tiene que ver, obviamente, con el concepto actual de «nación», que es un «territorio político» (por ejemplo, nos referimos a la nación española actual), que es distinto del de la Hispania romana. Esto sería ocioso recordarlo si no fuera porque todavía hoy podemos leer trabajos de historia antigua que se refieren a «los españoles en el ejército romano» o mencionan las «alas y cohortes españolas en los ejércitos romanos», conceptos, en fin, errados en su espíritu jurídico y en la noción exacta del territorio, que tanto irritan, y con razón, a nuestros vecinos portugueses. Claro que allí también hay quien habla del «Portugal romano».

${ }_{15}$ CIL XIII 8098. Museo de Bonn. Sobre esta estela funeraria, ver mi estudio titulado «La estela del signifer cohortis Pintaius (CIL XIII 8098). Apuntes iconográficos», Memorias de Historia Antigua 17, 1996, 255273.

16 De Ruggero, 1921, 32. 
neralizado de fórmulas funerarias) que tienden a ilustrar al lector de la inscripción. La epigrafía funeraria de los militares de época Julio-Claudia prefiere el término natio, en lugar de origo. Pero resulta casi más interesante incidir, en estos casos, en el interés de los soldados y de su entorno (de sus compañeros de armas) por fijar por escrito en el epitafio la patria del soldado. Es significativo que surja con los primeros emperadores la «necesidad emocional», diría yo, de poner en los epitafios la mención del lugar de nacimiento, pues fue el primer siglo d.C. cuando los soldados de las provincias comenzaron a engrosar regularmente los ejércitos romanos, esos ejércitos que se movían en apoyo de las legiones allí donde las necesidades estratégicas requiriesen su presencia.

No olvidemos nunca que el epitafio es un mensaje escrito que tiene un destinatario, y que en el caso de los militares difuntos los destinatarios del mensaje funerario eran, en primer lugar, los compañeros de armas. Por tanto cabe pensar que en muchos casos el legatario (el heres) y el difunto hubiesen nacido en un mismo lugar. Esto es muy posible, como también es posible que ambos soldados fuesen compañeros de armas y de unidad desde el momento de ser reclutados ambos en su convento jurídico.

Por tanto el lugar del nacimiento como primera patria del soldado, viene indicada expresamente por el término natio o domo, en ablativo, seguido del topónimo, tal como aparece frecuentemente en las inscripciones. Así y no de otra manera. Ver a tal propósito la siguiente tabla:

\section{MILITARES CON MENCIÓN DE ORIGO «HISPANUS» EXPLÍCITA}

\begin{tabular}{lll} 
Nombre y rango & Origo & Ref. y lugar del hallazo \\
\hline L. Licinius Hispanus, miles legionis & (domo) Palentinus & CIL V 920 Aquileia \\
M. Valerius Hispanus, eques de alae & domo Leonica & CIL IX 733 = ILS 2499 Larinum \\
Ti. Claudius Valerius, decurio alae & domo Hispano & CIL III 3271 Teotoburgium \\
L. Vitellius Tancinus, eques alae & cives Hispano, Caurie(n)sis & ILS 2517; RIB 159 Aquae Sulis \\
Reburrus, decurio alae & (domo) Hispano & CIL XVI 48 = ILS 2001 Malpas \\
P. Iulius Pintamus, ex decur.alae & domo ex Hisp.cit.; Aug.Bracara & AE 1972, 359 Aug.Vindelicorum \\
T. Iulius Urbanus, miles legionis & na(tione) Hispano & AE 1978, 342 Ferrara \\
T. Lucretius A[...], eques alae & ex Hispania, [Clu?]niensis & CIL XIII 11317 Augusta Treverorum \\
anónimo, eques alae & [nat(ione) Hisp]an(o) & CIL XIII 7027 Mogontiacum \\
L. Valerius Albinus, cent.? coh.I Thracum & domo Hisp(ano)? & CIL XIII 6286 Offenburg
\end{tabular}

No quiero dejar de apuntar una «razón psicológica» respecto al uso y costumbre de reflejar la patria en los epitafios. Parecía haber una razón existencial para ello: mencionar de la forma más precisa posible el lugar donde el difunto vio la luz, para que quedara el recuerdo allí donde reposaran sus huesos o sus cenizas y se hincara en tierra la lápida funeraria. Y esto se hacía por evocación sentimental de la patria o de la infancia, pero no tenía un sentido trascendental como el significado que le dieron a la muerte posteriormente los cristianos en el sentido de que 
la muerte del cuerpo es el nacimiento, el «primer día» del alma en el reino de Dios. No, para el soldado romano su sentido de trascendencia era algo así como un cierto interés de «permanecer en la memoria», o ser recordado por los vivos que quedan en este mundo; y para eso se hacían las inscripciones funerarias.

\section{1.b) La origo}

Un sentido más lato, más amplio en sentido geográfico y menos preciso semánticamente tiene el término origo. Este vocablo puede ser sinónimo de natio, aunque habrá que reconocer que los historiadores hablan muy frecuentemente de la origo de un personaje aun cuando ésta no está expresada en la inscripción, refiriéndose, más bien, a una origo deducida o inducida. En esencia debemos de hablar de una origo determinada cuando en la inscripción aparece expresada, por ejemplo una "origo hispana». Pero creo que es un error decir que la origo de un personaje coincide con el lugar donde fue hallado el epitafio, sin otro argumento textual o contextual.

Tácitamente el concepto origo parece tener mayor rango cultural que la natio. Aquél parece referirse a entidades geográficas de mayor entidad, más grandes en sentido territorial, o de mayor rango (por ejemplo mayor entidad urbana), tanto a nivel singular como regional.

En sentido estricto sólo podríamos hablar de «patria» en las menciones de natio y domus, ámbitos donde no hay contradicción o hay aproximación semántica entre pater y patria, siendo esta última la progenitora.

\section{1.b.1) Los cognomina equívocos de los soldados: etnónimos y origo}

Quiero también la atención sobre la cautela que debemos tener (que deben tener los epigrafistas de abordan el estudio del ejército) a la hora de asignar a un soldado una natio o una origo deduciéndola únicamente a partir de su cognomen formado por un etnónimo. En otro lugar he definido ${ }^{17}$ que los cognomina de origen geográfico, por sí solos, no garantizan la origo o procedencia de un individuo. Recordemos, por ejemplo, al beneficiarius consularis de un colegio militar de Lambaesis, llamado M.Valerius Aquileiensis, (origo) Thev(este) ${ }^{18}$.

$Y$ ello es del mismo modo aplicable al cognomen Hispanus, el cual, expresado solo, puede remitir necesariamente a un origen o procedencia directa del individuo

17 S. Perea Yébenes, «Hispanus Palentinus» Actas del III Congreso de Historia de Palencia. I: Prehistoria, arqueología e historia antigua, (Palencia 1995; public. 1997), 291-302.

18 S. Perea Yébenes, Collegia Militaria. Asociaciones militares en el Imperio romano, Madrid 1999, 402-407, y 522 texto \# 34). Tal opinión y con igual cautela se ha cuestionado la equívoca origo africana de un tal C. Minatius Africanus de otra inscripción aquileyense (CIL V 1302), vid. A. Calderini, Aquileia romana, Roma 1972 [reimpr. de la edición de 1930], 355, y G. Cuscito, «Africani in Aquileia e nell'Italia settentrionale», Aquileia e l'Africa; Antichità Altoadriatiche V, Udine 1974, 147. 
en cuestión, sino a una relación familiar. Dicho de otra manera: puede suceder que el Hispanus de origen hispano sea el padre o el abuelo ${ }^{19}$ pero no el Hispanus (no nacido en Hispania) descendiente que lleva el mismo nombre. $O$ aún más: puede llevarse ese cognomen por una relación de dependencia estatutaria personal, como el patronazgo.

En muchos casos existe una evidente contradicción entre la onomástica «toponímica" y la origo expresada. Así el luchador tracio llamado Macedonius (natione Alexandrinus) ${ }^{20}$, o el luchador samnita llamado Germanus (natione Greca) ${ }^{21}$, o bien el essedarius llamado Ingenuus Gallicia(nus) (natione Germanus) ${ }^{22}$. En los epitafios de los gladiadores, gentes generalmente de origen servil, nunca se menciona la domus para indicar su procedencia, sino la natio. Esta mención a la natio no sólo se hace constar, como se ha dicho ${ }^{23}$, para indicar regiones fuera de Italia ${ }^{24}$ sino más bien para indicar un nacimiento $u$ origen foráneo respecto al lugar donde el gladiador a muerto. Así sucede con Rapidus, reciario de Aquileia, caído en Salona, Dalmacia ${ }^{25}$.

\section{1.c) Las patrias «adoptadas»}

Otra patria (o patrias) del soldado se ubica (o ubican) allí donde está sirviendo, el destino o destinos sucesivos de su unidad militar. Naturalmente no es una «patria» capaz de modificar el estatuto jurídico del soldado, pero sí es una patria honorífica, especialmente si tal unidad ha intervenido victoriosamente en una batalla importante, o en una sucesión de episodios bélicos, o haber estado bajo el mando de un destacado general. En tal sentido no está de más recordar el interés de algunos emperadores en añadir a su onomástica, o mejor a su titulatura oficial, etnónimos honoríficos, como Parthicus, en el caso bien conocido de Trajano o de Septimio Severo, o Sarmaticus o Dacicus en el caso de Marco Aurelio, etcétera, tanto en inscripciones oficiales como en monedas ${ }^{26}$. Estos emperadores, en tales

19 Hay un Sempronius Hispanus en una inscripción de Palencia, CIL II 5770=CIP 53; una Hispanilla en Monte Cildá, Palencia, CIP 46. Un epígrafe de Talavera de la Reina cita a una Arria Hispanilla, madre de un soldado de la legión VII Gemina, véase F. Fuidio Rodríguez, Carpetania romana, Madrid 1934, 148 n. 27 ter y p.129; Le Roux, L'armée romaine et l'organisation des provinces ibériques d'Auguste a l'invasion de 409, Paris 1982, 231 n. ${ }^{\circ} 208$.

20 CIL VI 10197=ILS 5089

21 A. García y Bellido, «Lápidas funerarias de gladiadores de Hispania», Arch.Esp.Arq. 33, 1960, 13; P. Piernavieja, Corpus de Inscripciones deportivas de la España romana, Madrid 1977, 56.

22 García Bellido, «Lápidas», 5; Piernavieja, Corpus, 55.

23 P. Sabbatini Tumolesi, «Gladiatoria-|», Rendiconti Accademia dei Lincei 26, 1971, 745 n.41.

24 Los casos de n(atione) Mutinensis y de nation(e) Florentinus entre los gladiadores de la tabla III contradicen esta regla. Véase también CIL XI 112, CIL X 1967, 1968, 1978, 3474; y CIL III 896, 6611 y 14394.

25 Sabbatini, $1971,746$.

26 También la unidades militares toman sobrenombres honoríficos de origen étnicogeográfico, como las que ha estudiado Jeno Fitz para el siglo III d.C. en su libro Honorific Titles of Roman Military Units in the $3^{\text {rd }}$ Century, Budapest 1983. 
documentos, muestran, pues, también, un «etnónimo equívoco» en su titulatura, un nombre «adoptado» $y$ hecho oficial.

Es verdad que no sabemos si el soldado podía hacer lo mismo, y añadir un sobrenombre de este tipo «por escrito». Pero nadie podía impedirle en el ámbito de la convivencia castrense ser llamado con un nombre o mote alusivo a una patria adoptada por los muchos años de servicio que pasara un soldado en tal o cual lugar, especialmente si la instancia en un campamento o en una provincia ocupó gran parte de la vida profesional de un soldado. En tales casos, se exprese por escrito o no, tal lugar sería, de hecho, una patria para el militar. "La oveja es de donde pace no de donde nace», dice un refrán castellano.

Este lazo emocional explica suficientemente el hecho de que muchos soldados en el momento de la licencia decidan no volver a su verdadera patria (a su natio o domus) sino que se instalen, solos o con su familia, cerca de donde han servido a las águilas de Roma durante un buen puñado de años.

\section{1.d) Una patria ficticia pero legal: la origo castris}

La origo castris debe relacionarse con el cambio de los sistemas de reclutamiento, y, naturalmente con el lugar de nacimiento de «los soldados que son hijos de soldados". El fenómeno puede estudiarse bien en Egipto y en África. Una monumental inscripción de Nicopolis de Egipto, que da los nombres de 134 soldados de las legiones establecidas en el país, nos informa de que más de la mitad de ellos eran originarios de África y de Numidia, por tanto «ciudadanos de Roma» nacidos en Ammaedera, en Theveste, Cirta o Cuicup ${ }^{27}$. El reclutamiento de los soldados de la legión III Augusta, muy bien estudiado, demuestra igualmente el espectacular progreso de la aportación del elemento africano a esta legión con el correr de los primeros siglos del Imperio ${ }^{28}$.

En Numidia, en época severiana, vemos que el gran campamento estable de la legión III Augusta en Lambaesis se nutre en el 97\% de soldados norteafricanos, abarcando poblaciones que se mueven en un radio aproximado de $500 \mathrm{~km}$. Ello

27 P.-A. Février, Approaches du Maghreb romain, II. Pouvoir, différences et conflicts, Aix-en-Provence 1990, 102-103, con más ejemplos de militares africanos en los ejércitos europeos del Danubio (en la legión I Italica), y en Germania (la I Minervia), en el Rhin (la XXII Primigenia), etc. Gaius Artorius Tertullus, un veterano del ejército, es flamen perpetuus de Thubursicu Numidarum; de este mismo lugar es Caius Vasidius Bellicus, que militó en la $X$ cohors Urbana y optio ab actis en Roma. Esta experiencia de litteratus en el ejército le sirvió para su carrera posterior municipal como edil y duoviro. Basten estos ejemplos entre otros muchos.

${ }_{28}$ Y. Le Bohec, La Troisième Légion Auguste, 495-502. En el periodo 117-161 se constatan epigráficamente 166 soldados de origen africano (y 115 extranjeros), y en el periodo 193-238 los africanos son 501 (casi triplica la cifra anterior) y los extranjeros 24, dividiendo por más de cuatro veces su presencia en esta legión para este periodo. No ha de pasar inadvertido que esta fortísima presencia de africanos en la III Augusta se produce durante la dinastía severiana, sobre todo a partir su fundador Septimio Severo, igualmente africano. 
abarca en dirección oeste la parte de Mauretania Cesariense lindante con Numidia (Cuicul; y más lejos Tipasa) pero que en conjunto tampoco aportan gran número de efectivos. En cambio hacia el Este, la recluta abarca prácticamente toda la provincia de Numidia y toda la Proconsular, desde Hippo o Utica en el norte hasta Telepte en el sur ${ }^{29}$. La gran zona desértica entre las poblaciones del sur de Numidia (Theveste) o la Proconsular (Cillium, Telepte, etc) hasta la Tripolitania, sabemos que en época severiana estaba recorrida y vigilada por destacamentos de la legión III Augusta ${ }^{30}$. En inscripciones colectivas africanas se detecta también una alta presencia de soldados con origo castris, aproximadamente el 15\%.

András Mócsy aseguraba que la origo castris era una fictio para indicar la particular condición jurídica de los hijos de los soldados/mujer peregrina, nacido no necesariamente en las canabae, aunque sí quizás en relación con el ambiente militar de frontera ${ }^{31}$. Existe en África tan elevado número de hombres con origines "castris» que los datos comparativos interprovinciales no son homologables. Una de las causas determinantes de tal hecho es sin duda el mayor número de documentos epigráficos, que pueden darnos una visión sesgada del conjunto, aunque, a mi juicio tal circunstancia no invalida los resultados obtenidos del estudio de la prosopographia militum de la legión III Augusta, y creo que el hecho de no conocer con tanto detalle los origines de los soldados en otras provincias no debe excluir la posibilidad de otorgar un número similar de origines castris en otras zonas fuertemente militarizadas ${ }^{32}$, como las provincias del área reno-danubiana.

El levantamiento, por parte de Septimio Severo, de la prohibición que pesaba sobre los soldados de acceder a un iustum matrimonium, repercutió no sólo en la modificación de los estatutos de sus familiares, esposa e hijos naturales, sino también en el uso de la onomástica. Barkóczi, que ha estudiado bien la población de Panonia durante los siglos II-III d.C., ha observado, a propósito de la onomástica y de los matrimonios (independiente de su «legalidad») que a partir de Marco Aurelio se tiende, entre los militares, a cierta uniformidad de usos onomásticos ${ }^{33}$. Una de las razones es la conexión cada vez mayor entre fuerzas auxiliares y las legiones. Hijos de veteranos que sirvieron en alas o cohortes auxiliares se enrolan en las legiones y, el caso contrario, hijos de legionarios que se alistan en cuerpos auxiliares $^{34}$. Si existía alguna descriminación respecto al nombre de hombres que ser-

29 S. Perea Yébenes, Collegia Militaria, 1999, 403-404.

30 ILAfr. 8-9.

31 A. Mócsy, «Die origo castris und die canabae», Acta Archaeologica Academia Scientiarum Hungaricae 13, 1965, 425431 = Pannonien und des Römischen Heer, (Stuttgart: Mavors 7, 1992), 174180.

32 A. Mócsy, «Das Territorium Legionis und die Canabae in Pannonien»,Acta Archaeologica Academia Scientiarum Hungaricae 3, 1953, S.179-199. A. Forni, «Estrazione etnica e sociale dei soldati deIle legioni nei primi tre secoli dell'impero», ANRW II.1, 1974, 389; F. Vittinhoff, « Die Rechtliche Stellung der canabae legionis und die Herkunftangabe castris", Chiron 1, 1981, 314-318 (= Civitas Romana. Stadt und politisch-sociale Integration im Imperium Romanum der Kaiserzeit. Stuttgart, 1994, 140 ss.).

${ }^{33}$ L. Barkóczi, «The Population of Pannonia from Marcus Aurelius to Diocletian», Acta Archaeologica Academia Scientiarum Hungaricae 16, 1964, 257 ss.

34 Barkóczi 1964, 289. 
vían en la misma unidad, tal discriminación cada vez era menor, y fue abolida definitivamente con la Constitutio Antoniniana.

David Noy, en un libro reciente ${ }^{35}$, ha meditado sobre la definición del término «extranjero» o «foráneo / forastero». Da justa importancia al tiempo de residencia, a la duración, es decir, "dónde se vive normalmente», en Roma, en una ciudad de Italia, en las provincias o fuera de los límites del Imperio. Es la continuidad lo que crea vínculos de dependencia social y estatutaria del individuo con la sociedad que lo acoge. Por tanto, el soldado puede sentirse (y de hecho se sentía) «despatriado» o forastero en todo lugar, salvo en su mundo, su mundus, el campamento. Allí se conjugan en un mismo lenguaje los anhelos de los soldados que vienen de cualquier parte del mundo, toû kósmoû.

\section{1.e) El retiro del soldado, ¿nuevas patrias para los veteranos? El caso de los jinetes de «alae hispanorum»}

Otra patria «adoptada» del soldado es aquella en la que vive o donde se instala una vez licenciado. Digo adoptada porque no es una patria «natural», pero es «real» por cuanto tiene soporte jurídico — su legalidad se sustancia o certifica, en el caso de los auxilia, mediante un diploma emitido por la cancillería imperial—, y, sobre todo, porque es una realidad.

Al hablar de las unidades auxiliares, de la enorme cantidad de ellas a lo largo de todo el Imperio (la época y el territorio imperiales) ${ }^{36}$, conviene tener presente una cosa: que el elemento humano de una determinada unidad - cohorte de infantería, ala de caballería, o cohorte mixta (las cohortes equitatae) - coincide con el etnónimo sólo en el primer momento, en su reclutamiento y constitución primera, original. Es decir, una cohors Asturum está compuesta de astures en su formación y primera hornada, pero no necesariamente en las siguientes. Es obvio que una cohors Asturum que se traslada, por ejemplo, a Britannia por necesidades estratégicas no puede alimentarse continuamente, cubriendo sus bajas o con aportación de nuevas levas, por astures y siempre por astures. La densidad de población joven en la Asturia hispana hace casi imposible esa opción. Y lo mismo puede decirse de otras regiones. El nombre de la unidad permanece, el elemento humano se mezcla y cambia continuamente. Puede suceder, incluso, que, pasadas varias generaciones ¡no haya ni un solo astur en una cohors Asturum ${ }^{37}$. Cuando el

35 D. Noy, Foreigners at Rome: citizens and strangers, London 2000.

36 Síntesis generales sobre este tipo de unidades: C. Cichorius, voz «Ala», RE, 1894, cols.12231270, renovado y actualizado por J. Spaul, Cohors-2. The evidence for and a short history of the auxiliary infantry units of the Imperial Roman Army, Oxford, BAR-IS 841, 2000 (aunque esta obra, que debe ser usada con cautela por sus numerosos errores referenciales, no sustituye a la anterior). Una visión de conjunto, más allá del mero repertorio, aunque antigua, es la obra de G.L. Cheesman, The Auxilia of $t$ he Roman Imperial Army, [Oxford 1914] (reimpresión en HildesheimNew York 1971).

37 En el diploma CIL XVI 82. 
aporte humano de otras etnias es muy significativo, o se amalgama con otra, la unidad puede aparecer con un nombre doble, por ejemplo el ala prima Asturum et Tungrorum, en el año 135 en Britania ${ }^{38}$. O también puede ocurrir que el nombre secundario (secundario en un primer momento) suplante el nombre de la unidad. Esta idea puede ser muy interesante a la hora de evaluar la continuidad de una unidad u otra en un territorio, o su dislocación. De modo que la aparición de una nueva unidad no conllevaría un aporte suplementario de hombres sino sólo un cambio de denominación. Así se explican, al menos en parte, esos vacíos o carencias de numerales consecutivos en algunas series de unidades auxiliares, o bien la aparición de otras nuevas con etnónimo nuevo y un numeral muy alto (desconociéndose la ubicación y dudándose de la existencia de sus correspondientes unidades con el mismo nombre y numerales inferiores).

Aún teniendo en cuenta estas consideraciones, al menos para los primeros tiempos de cada una de las unidades auxiliares cabe pensar, en todas y en cada una de ellas, en un «exilio» forzado de la unidad de sus soldados y mandos por las necesidades de servicio. Veamos en la tabla siguiente los avatares de las unidades de caballería con nombre y origen «hispano» en el Alto Imperio, su fecha y su localización, a partir de la información que nos proporcionan los diplomas militares de los jinetes en el momento de su licencia honrosa:

ALAS CON NOMBRE U ORIGEN HISPANO MENCIONADAS EN LOS DIPLOMAS ${ }^{39}$

\begin{tabular}{llll} 
Alae «hispanorum» & Datac. & Provincia & Ref. diploma \\
\hline I Asturum & 99 & Moes. Inf. & CIL XVI 45 \\
& 140 & Dacia Inf. & RMD I 39 \\
I Asturum et Tungrorum & 135 & Britannia & CIL XVI 82 \\
II Asturum & 122 & Britannia & CIL XVI 69 \\
III Asturum pia fidelis c.R & 88 (III A.) & Maur. Ting. & CIL XVI sup. 159 \\
& 109 & Maur. Ting. & CIL XVI sup. 161 \\
& $114 / 117$ & Maur. Ting. & CIL XVI sup. 165 \\
& $121 / 128$ & Maur. Ting. & CIL XVI 73 \\
III Asturum c.R & 122 & Maur. Ting. & CIL XVI sup. 169, 170 \\
& 159 & Maur. Ting. & RMD I 53 \\
Astures, etiam s. Hispani & 161 & Maur. Ting. & RMD II [107] \\
Auriana v.s. Hispani & $162 / 203 ?$ & Maur. Ting. & RMD III 186 \\
I Hispanorum & 83 & Aegyptus & CIL XVI 29 \\
I?Hispanorum & $144^{*}$ & Dacia Sup. & CIL XVI 90 \\
I Hispanorum Arevacorum & 129 & Dacia Inf. & CIL XVI 75 \\
& 140 & Dacia Inf. & RMD I 39 \\
& 80 (I A.) & Pannonia & CIL XVI 26 \\
& 80 (I. A.) & Pannonia & RMD III [138] \\
& 84 (I A.) & Pannonia & CIL XVI 30
\end{tabular}

38 CIL XVI 82. RMD.

39 Se dan referencias epigráficas hasta 1993, fecha del tercer volumen del repertorio de M. Roxan, 


\begin{tabular}{|c|c|c|c|}
\hline Alae «hispanorum» & Datac. & Provincia & Ref. diploma \\
\hline & 85 (I A.) & Pannonia & CIL XVI 31 \\
\hline & 102 & Pannonia & CIL XVI 47 \\
\hline & 113 & Pann. Sup. & RMD ॥ 86 \\
\hline & 133 & Pann. Sup. & CIL XVI 77, 77 \\
\hline & 138 & Pann. Sup. & CIL XVI 84 \\
\hline & 146 & Pann. Sup. & CIL XVI sup. 178 \\
\hline & 148 & Pann. Sup. & CIL XVI 96 \\
\hline & 149 & Pann. Sup. & CIL XVI 97 \\
\hline & 150 & Pann. Sup. & CIL XVI 99 \\
\hline & 154 & Pann. Sup. & CIL XVI 104 \\
\hline & 163 & Pann. Sup. & RMD I 62 \\
\hline \multirow[t]{4}{*}{ I Hispanorum Asturum } & 98 & Britannia & CIL XVI 43 \\
\hline & 122 & Britannia & CIL XVI 69 \\
\hline & 124 & Britannia & CIL XVI 70 \\
\hline & 146 & Britannia & CIL XVI 93 \\
\hline \multirow[t]{16}{*}{ I Hispanorum Auriana } & 107 & Raetia & CIL XVI 55 \\
\hline & 116 & Raetia & RMD III 155 \\
\hline & $121 / 125$ & Raetia & RMD I 25 \\
\hline & $125 / 128$ & Raetia & RMD I 32 \\
\hline & $138 / 140$ & Raetia & RMD II 94 \\
\hline & $139 / 140 ?$ & Raetia & RMD III 164 \\
\hline & $140 / 144$ & Raetia & RMD II [58, 95] \\
\hline & $147^{\star}$ & Raetia & CIL XVI 94 \\
\hline & $122 / 157$ & Raetia & CIL XVI 105 \\
\hline & 153 & Raetia & RMD | 46 \\
\hline & $153 / 157$ & Raetia & RMD I 51 \\
\hline & $156 / 157$ & Raetia & CIL XVI sup. 183 \\
\hline & $156 / 157$ & Raetia & RMD II 51, 104 \\
\hline & 157 & Raetia & RMD III 170 \\
\hline & $149 / 161$ & Raetia & RMD I 59 \\
\hline & $154 / 161$ & Raetia & RMD III [175] \\
\hline \multirow[t]{4}{*}{ I Hispanorum Compagonum } & 114 & Pann. Inf. & RMD III 153 \\
\hline & 144 (I H.) & Dacia Sup. & CIL XVI 90 \\
\hline & 157 & Dacia Sup. & CIL XVI 107 \\
\hline & 158 & Dacia Sup. & CIL XVI 108 \\
\hline \multirow[t]{2}{*}{ Hispanorum Vettonum c.R. } & 103 & Britannia & CIL XVI 48 \\
\hline & ante 114 & Britannia & RMD III 151 \\
\hline (V.H. c.R) & 122 & Britannia & CIL XVI 69 \\
\hline Vettonum Hispanorum & 178 & Britannia & RMD III 184 \\
\hline \multirow[t]{7}{*}{ II Hispanorum Arevacorum } & 80 (II A.) & Pannonia & CIL XVI 26 \\
\hline & 80 (II A.) & Pannonia & RMD III 138 \\
\hline & 84 (II A.) & Pannonia & CIL XVI 30 \\
\hline & 85 (II A.) & Pannonia & CIL XVI 31 \\
\hline & 99(II H. et A.) & Moes. Sup. & CIL XVI 44 \\
\hline & 145 & Moes. Inf. & RMD III 165 \\
\hline & $157 ?$ & Moes. Sup. & RMD I 50 \\
\hline
\end{tabular}


Cualquier unidad o grupo de unidades «provinciales» podría haberse tomado como ejemplo igualmente válido para ilustrar esa idea de exilio patrio. Miles de kilómetros de distancia desde su lugar de reclutamiento, decenas de batallas, días, semanas, años de servicio... ¿Cuál era la patria verdadera de estos soldados? La respuesta, al contrario de lo que pueda parecer, es fácil: Todas y ninguna. ¿Por qué? Porque había un sentimiento —un compromiso político y vital- de pertenecer a una entidad de orden superior, el Imperium Romanum.

No cabe duda de que el ejército romano imperial es un verdadero crisol de etnias y de pueblos, donde «barbarie» y «romanidad» se dan la mano. Existía una fórmula política - desde época de Augusto al menos de forma institucionalizadade integrar a las naciones vencidas en la estructura política del Imperio. Los pactos de hospitium son la mejor evidencia jurídica de esta forma de integración política en tiempos de expansión militar y de conflictos inter-étnicos e interculturales. Una muestra del genio político romano fue advertir la importancia que tenía integrar en su propia maquinaria bélica, en el ejército romano, a los sus enemigos más peligrosos. Las tribus vencidas, principalmente aquellas que tenían especial habilidad en el arte militar, fueron incorporadas a la estructura del ejército romano como auxiliares. Bastará recordar como ejemplo de esto a los lusitani hispanos, que constituyen una de las canteras más solidas de soldados de infantería auxiliar romana, repartidos y luchando por todo el Imperio desde el siglo primero y durante varios siglos más. Otro ejemplo de sometimiento e integración, cultural y militar es el de la tribu de los musulamii africanos, que he estudiado en otro lugar ${ }^{40}$, gentes de los límites del desierto sahariano, experimentados en la guerra, como nos cuenta Tácito en dos capítulos dispersos pero referentes ambos a la revuelta del númida Tacfarinas $^{41}$, y que luego, en el año 45 intervienen en los conflictos armados sirviendo bajo las banderas del futuro emperador Galba, según el historiador Aurelio Víctori2; poco más tarde tenemos noticia ya de una cohorte identificada únicamente por el topónimo o gentilicio regional y una cohors I Flavia Musulamiorum reclutada entre las mismas gentes, una vez pacificado su territorio en el año 70 , en tiempos de Vespasiano.

Es de todos sabido que los soldados auxiliares alistados en el ejército romano tenían la promesa de obtener la ciudadanía romana al final de su carrera militar, en el momento mismo de su licencia, si es que estaban vivos y la licencia era honrosa

40 S. Perea Yébenes, «Los musulamii norteafricanos y el ejército romano», en mi libro Hispania romana y el norte de África, Sevilla 2003, cap. II, 51-66. Sobre las tropas auxiliares romanas en el norte de África: Y. Le Bohec, Les unités auxiliaires de l'armée romaine en Afrique Proconsulaire et Numidie sous le HautEmpire, AixMarseille, 1989; Chr. Hamdoune, Les auxilia externa africains des armées romaines, iiie siècle av. J.C.ive siècle ap. J.C, Montpellier, Université PaulValéryMontpellier III, 1999.

41 Tac. Ann. II, 52, non inconditae turbae sed Musulamiorum dux haberi; Ann. IV, 24: simul principes Musulamiorum defectionem cooptantis securi percutit. Ver también Tac. Ann. II, 20-21, 32, 75, 73-74; IV, 23-25; y el estudio de R. Syme, «Tacfarinas, the Musulamii and Thubursicu», en P.R. Coleman-Norton (ed.), Studies in Roman Economic and Social History in honor of Allan Chester Johnson, Princeton 1951, 113-130 = Roman Papers, I, Oxford 1979, 218-230.

42 De Caes. IV, 2. 
(honesta missio). Cientos de documentos epigráficos — los diplomas militares ${ }^{43}$, relativos a soldados de infantería, jinetes y marineros - certifican esta práctica jurídica vigente, jvigorosamente vigente!, en los dos primeros siglos del Imperio ${ }^{44}$.

Los beneficios jurídicos de la licencia honrosa del soldado auxiliar afectaba también, positivamente, a su «unidad familiar», esposa e hijos ${ }^{45}$, que al mismo tiempo que el padre veían mejorado su estatuto jurídico. Los hijos de estos auxiliares «veteranos», si es que alistaban alguna vez en el ejército, ya podían enrolarse como legionarios y luchar codo con codo con un compañero de armas cuya familia podía tener el estatuto de "ciudadano» desde varias generaciones anteriores.

Eso es lo verdaderamente importante: guardar en la medida de lo posible (más en la apariencia, en las formas, que en la realidad cotidiana) las particularidades originarias (de la origo de cada uno) pero teniendo ellos, los soldados, la conciencia y la certeza de que esas singularidades eran limadas y borradas por la pertenencia, sin más, al ejército del emperador. Esta condición pública (profesional y/o política) prevalecía sobre las demás cuestiones particulares que podían ha-

${ }^{43}$ Estos documentos pueden consultarse en varios corpora epigráficos, que cito: Los diplomas $n .{ }^{\circ} \mathrm{S}$ 1-189 están editados en CIL XVI, siguiendo un orden cronológico, en sendos volúmenes publicados: $\mathrm{CIL}$ XVI: Diplomata Militaria. Ex constitutionibus imperatorum de civitate et conubio militum veteranorumque expressa, (post Th. Mommsen, edidit H. Nesselhauf), Berlin $1936+$ CIL XVI Supplementum. Diplomatum Militarium. Ex constitutionibus imperatorum de civitate et conubio militum veteranorumque expressorum, (edidit H. Nesselhauf), Berlin 1955. Esta publicación tiene continuación en su contenido y espíritu, en la obra conocida con las siglas RMD (Roman Military Diplomas), obra de la citada M. Roxan, que es Investigadora Honoraria en el Instituto de Arqueología del University College de Londres. Los tres volúmenes aparecidos llevan numeración propia: RMD I: M. Roxan: Roman Military Diplomas 1954-1977, London 1978, estudia los diplomas n. ${ }^{\circ}$ 1-78; RMD II: M. Roxan: Roman Military Diplomas 1978-1984, London 1985, los diplomas n. ${ }^{\circ}$ 79-135; y RMD III: M. Roxan: Roman Military Diplomas 1985-1993, London 1994, los diplomas n. ${ }^{\circ} 136-200$ (+1 en un apéndice). En todos los casos estos volúmenes abren con la revisión de documentos publicados antes, en una u otra serie. La epigrafía novísima de estos documentos viene siendo publicada en revistas especializadas, como ZPE, Chiron, etc.

${ }_{44}$ Sobre aspectos culturales y jurídicos de los diplomas militares, cito las principales referencias bibliográficas por orden alfabético: G. Alföldy, «Zur Beurteilung der Militärdliplome der Auxiliarsoldaten», Historia 17, 1969, 215-227. A.W. van Buren, «Some Families formed by Roman Soldiers and Veterans," Hommages à A. Grenier, Bruxelles 1962, 1564-1570. [Collection Latomus, 58]. D. Cherry, «Roman Soldiers' Marriages," Ancient History Bulletin 3 ,1989, 128-130. W. Eck, H. Wolff (eds.), Heer und Integrationspolitik: die Römische Militärdiplome als historischer Quelle. Passauer Historische Forschungen 2 (Köln Wien 1986). Cf. Recensión: JRS 79, 1989, 227-228. P. Le Roux, "Les diplômes militaires et l' évolution de l' armée romaine de Claude à Septime Sévère: auxilia, numeri et nationes," Heer und Integrationspolitik, 1986, 347-374. R. Mac Mullen, Soldier and Civilian in the Later Roman Empire, 1963, 715, 98-118. J.C. Mann, «The Development of Auxiliary and Fleet Diplomas», Epigraphische Studien 9, 1972, 233-241. S.E. Phang, The marriage of Roman Soldiers (13 BC - AD 235). Law and Family in the Imperial Army. Columbia Studies in the Classical Tradition, Brill. Leiden - Boston - Köln, 2001, espec. 5385. R.F. Renz, The Legal Position of the Soldier and Veteran in the Roman Empire, Dissertation: Fordham University 1972. M.M. Roxan, J. Morris, «The Witnesses to Roman Military Diplomas," AArch Slov 28, 1977, 299-333. H.T. Rowell, "The honesta missio from the Numeri of the Roman Imperial Army", Yale Classical Studies 6, 1939, 71-108. A. Segre, "ll diritto dei militari peregrini nell' esercito romano,» RPAA $17,1940 / 41,167-182$. W. Seston, «Les vétérans sans diplômes dans les légions romaines,» RPh 7, 1933, 375-395. R.E. Smith, «The Army Reforms of Septimius Severus,» Historia 12, 1972, 481-500.

${ }_{45}$ Como se explicita en la fórmula «tópica» de los diplomas (con leves variantes, y con palabras abreviadas en cada caso): «honesta missione, quorum nomina sub scripta sunt civitatem romanam qui eorum non haberent, dedit et connubium cum uxori uxoribus quas tunc habuissent, cum est civitas iis data, aut cum is qua postea duxissent dumtaxat singulis. 
cerse constar o notar, eso sí, en el momento de la muerte, en el discurso coloquial en la frontera de esta vida con la otra, y en las conversaciones y promesas que se hacen entre los compañeros de armas. Perder mucho para ganar más. Esa es la grandeza y miseria de esta extraordinaria maquinaria bélica, política y humana, capaz de transformar países, instituciones y mentalidades.

\section{1.f) La «patria fuera de la patria»: la «unidad étnica» como nación}

No quiero extenderme en este punto, sino únicamente recordar algunos ejemplos para que se entienda esta idea. Hay unidades militares que se forman a instancias de un emperador para servirle como guardia de corps. Son militares pero en cierta medida están organizados y existen como tal unidad al margen de la estructura general del ejército. Su función en todos los casos es la misma: actuar como guardia personal del emperador; y tienen un denominador común: pertenecer a una misma etnia. Y no solo a una misma etnia sino a una etnia bárbara, y por ende belicosa, especialmente fiera y temible.

El origen de estos cuerpos especiales hay que buscarlo en las guerras del siglo I a.C., donde tropas étnicas se «atan» a un jefe militar romano (a los imperatores republicanos), asegurando su fidelidad mediante lazos religiosos (la devotio) o profesionales. Basta recordar a los calagurritani que hicieron voto de servicio a Marco Antonio, a vida o muerte ${ }^{46}$.

En el siglo I, el emperador Claudio se había rodeado también, para la protección de su persona, de una guardia étnica de Bátavos, los Germani corporis custo$d \mathrm{~s}^{47}$; y posteriormente los equites singulares Augusti ${ }^{48}$ tienen las mismas características. Tienen una especial relevancia a finales del siglo II y en época severiana.

Esta misma idea de «blindaje étnico» en la guardia imperial tiene paralelo (o es consecuencia) de la estructura y sistema de reclutamiento de los pretorianos, que procedían exclusivamente de Italia, al menos en los dos primeros siglos del Imperio. Tras la reforma de las cohortes pretorianas operada por Septimio Severo, los soldados pretorianos no se reclutaban sólo en Italia, sino también en las anti-

${ }^{46}$ Ejemplo que imitó Augusto tras vencer a Antonio y reorganizar las fuerzas militares, según Suet. Aug., 49,12: Ex militaribus copiis legiones et auxilia provinciatim distribuit, classem Miseni et alteram Ravennae ad tutelam Superi et Inferi maris conlocavit, ceterum numerum partim in urbis partim in sui custodiam adlegit dimissa Calagurritanorum manu, quam usque ad devictum Antonium, item Germanorum, quam usque ad cladem.

47 He tratado este tema en mi libro Collegia Militaria, 1999, 143-148. Las inscripciones relativas, en p. 144.; y la bibliografía pertinente en las notas, entre las que destaco el título: C. Ricci, "Germani a Roma. Roma.Testimonianze epigraphiche romane tra I e II sec.d.C.», Polis 5, 1993, 205225, y sobre todo: M.P. Speidel, «Germani Corporis Custodes», Germania 62, 1984, 3145 = Roman Army Studies II (Amsterdam: Mavors 8, 1992), 105119.

${ }_{48} \mathrm{~A}$ los que M. P. Speidel ha dedicado libros imprescindibles para su estudio: Die Equites singulares Augusti. Begleittruppen der römischen Kaiser des zweiten und dritten Jahrhunderts, Bonn 1975. Id., The Guards of the Roman Armies. An Essay on the Singulares of the Provinces, Bonn 1978. Id., Die Denkmäler der Kaiserreiter, Equites Singulares Augusti (edición en inglés: The monuments of the imperial horse guards, Equites Singulares August), Köln 1993. Id., Riding for Caesar. The Roman Emperors' Horse Guards, Harvard University Press: Cambridge (U.K.), 1994. 
guas colonias de cualquier provincia del imperio, dándose en la guarnición de Roma a comienzos del siglo III, según Fulvio Grosso, «una specie di promiscuità etnica tra pretoriani, equites singulares Augusti e legionari della II Parthica» "49.

Allí donde van los singulares Augusti, a Roma o a Mesopotamia, la etnia es su identidad, y prevalece sobre toda otra consideración. Son, si se me permite la metáfora, una «burbuja germana» móvil dentro del cuerpo del Imperio, situándose siempre cerca del corazón, del motor (el emperador) para cuidarlo. Las tropas de germani llevan la patria consigo.

\section{ELEMENTOS DE INTERCULTURALIDAD Y DE RUPTURA DE SINGULARIDADES ÉTNICAS}

\section{2.a) El campamento, cosmopolis}

Si tal como se ha dicho hasta la saciedad las ciudades de las provincias trataron de ser (y de hecho eran) «una pequeña Roma», también, creo yo, puede decirse que el perímetro de un campamento puede tomarse como símil del Imperio romano: un mundo bien organizado en su compleja diversidad de funciones y de gentes. En fin, un campamento es también un pomerium y una civitas.

Pero la metáfora admite una comparación más humilde, pues el campamento romano, en su cotidianidad es una unidad de convivencia - casi una ciudadcuyo rasgo humano más característico es su pluralidad y pluralismo de gentes, una cosmopolis, o al menos, como se ha insistido modernamente, «una comunidad» 50 . Cientos de hombres (en el caso de las unidades auxiliares) o miles (en caso de los campamentos legionarios) conviven dentro de los muros del campamento - una especie de recinto pomerial perfectamente delimitado- con sus leyes, sus mandos, su religión y sus ratos de ocio.

Ese cosmopolitismo «cívico militar», como me he atrevido a calificar, lo era en grado creciente según iban avanzando los años y las dinastías a lo largo de los tres primeros siglos del Imperio. Imaginamos la convivencia de soldados de muchas procedencias, con sus lenguas distintas, sus costumbres y recuerdos dibujados en conversaciones mantenidas a la luz del fuego, en las barracas, antes de sueño de la noche. Se hablaría de dioses patrios, de costumbres culinarias o de paisajes dejados atrás, o de familias que jay! muchos no volverían a ver jamás. Esos referentes culturales del ámbito privado del soldado se difuminan en el ámbito público -es decir, a la luz del día, en el trabajo de campo o en el escenario de la batalla - donde no hay más dioses que los de Roma, no hay más comida que la del rancho, no hay más paisaje que el entorno del campamento o las líneas enemigas, y no hay más familia que los compañeros de armas.

49 F. Grosso, «Equites singulares Augusti», Latomus 25, 1966, 905.

50 A. Goldsworthy / I. Haynes (eds.): The Roman Army as a Community. London 1999 (Journal of Roman Archaeology supplementary series nr. 34). 
El oficio, el instinto natural de supervivencia, la guerra misma (el miedo a la muerte y la alta tensión por la victoria), eso es lo que engrandece la existencia del soldado y lima los particularismos de origen hasta casi anularlos o convertirlos en anécdota.

\section{2.b) El emperador como general en jefe de todos los soldados (Hadriano en el norte de África)}

Busquemos una foto fija, o una secuencia de pocos minutos en lo que podría muy bien ser una película peplum. El escenario principal es Lambaesis, en la provincia romana de Numidia. El protagonista es, ni más ni menos, que el mismo emperador Hadriano, sobre su caballo, pasando revista a las tropas ${ }^{51}$. Detrás de él iba la escolta personal siguiéndole los pasos, y a su lado el legado de la gran legión III Augusta, Quintus Fabius Catullinus ${ }^{52}$. Son los jefes militares supremos allí de un ejército que permanece en formación a cielo abierto, un seguramente caluroso día del mes de julio del año 128. Para la ocasión los soldados de infantería mostraron sus habilidades con las armas, en ejercicios individuales o colectivos, y los jinetes realizaron maniobras de exhibición y entrenamiento ${ }^{53}$, realizando carreras y simulando combates.

La visita del emperador tenía como finalidad comprobar el nivel de preparación de los soldados, sus entrenamientos y sus técnicas de combate. La memoria de la visita de Hadriano en 128 se ha conservado en una larga inscripción conmemorativa con la adlocutio del emperador a las tropas ${ }^{54}$, como había hecho quizás en otros punto del norte de África, en otras guarniciones de menor entidad, por ejemplo pero también en Zraïa. Hadriano viajó expresamente al norte de África para inspeccionar las tropas, presenciar sus ejercicios, y comentarlos en presencia de sus soldados, y arengarles si lo creyera preciso. Esta teoría relega a segundo lugar aquellas interpretaciones de los historiadores, siempre genéricas, que decían que la visita a las tropas era sólo una pequeña parte de una especie de «viaje turístico» del emperador, o bien, como también se ha sugerido, buscar un público fiel para exhibir su arte oratoria.

51 Un caso similar lo tenemos en Germania, en el octubre del año 39, en que Calígula reunió a las tropas germanas para pasar revista en calidad de general en jefe (Suet. Calig. 43 y 44.1 ). En realidad este fue «la actuación militar» más importante de este emperador.

52 C. Wolff, «Q. Fabius Catullinus, légat de la IIIe légion Auguste», en: Avec la collaboracion de J.-F. Berthet, G. Brizzi, V. Giuffrè, J.-M. Lassère, J.L. Voisin et Ch. Wolff: Les discours d'Hadrien à l'armée d'Afrique. Exercitatio. Paris 2003. Editions De Boccard, 53-55. Sobre Catulino y la visita de Hadriano, añadir: S. Perea Yébenes, Águilas de plata. Lecturas sobre ejército romano y religión, Madrid 2006, cap. 4.

53 Sobre el entrenamiento de la caballería, R.W. Davies, «The training grounds of Roman cavalry», The Archaeological Journal, 125, 1968, 173-100. Sobre los campamentos «de entrenamiento» de la caballería, Y. Le Bohec, «Le pseudo camp des auxiliaires à Lambese», C.G.R.A.R., I, 1977, 71-85.

54 Sólo recientemente disponemos de una edición crítica del conjunto epigráfico que relata esta visita imperial y los discursos pronunciados a las distintas unidades. El puzzle epigáficos formaba parte de un monumento conmemorativo de la visita de Hadriano a África constaba de una columna y una gran basa monumental revestida con los textos. Sobre el tema, ahora fundamental para estudios de estrategia y de mentalidades en el ejército del s. II, remito a la obra, citada en notas previas, dirigida por Yann Le Bohec (ed.), Les discours d'Hadrien à l'armée d'Afrique. Exercitatio, Paris 2003. 
Con el acto presidido por Hadriano en Lambaesis, y con el discurso que le da forma literaria y calidad de documento histórico, se pretendía demostrar, según Yann Le Bohec, «la superioridad total del soldado romano sobre el bárbaro» 55 . Pero, ¿qué bárbaros? ¿Acaso las tropas que fueron inspeccionadas por el emperador y participaron en estas exhibiciones eran todos ciudadanos romanos de Italia? ¡Obviamente no! ¿Nos referimos entonces al bárbaro nómada que hostigaba las fronteras $\mathrm{o}$ el espacio de seguridad que controlaban los jinetes romanos? Creo yo que se opone a bárbaro, para Hadriano, no aquél que procede de una región extrema del Imperio, sino el que no vive según las leyes de Roma. Los anteriormente citados musulamii eran»bárbaros» cuando combatían contra Roma, y eran «como romanos» cuando se integraron en una de sus cohortes auxiliares defendiendo los estandartes del Imperio.

Por tanto, Hadriano en Lambaesis se dirige a sus hombres, a los soldados de Roma, cualquiera que sea su origen, su nombre (o el nombre de su unidad), su tez, o su lengua materna. Todos -está claro- entendían el latín en el que se expresaba el emperador. Posiblemente el griego de Hadriano fuera más elegante, más retórico sin duda, pero sabía que, en ese lugar y en ese momento, sólo podía hablar en latín, la lengua de los soldados.

Allí estaban, que sepamos al menos, todos los mandos y tropas de infantería y de caballería de la legión III Augusta, y posiblemente los auxilia de dos o tres alas de caballería y otras tantas de cohortes de infantería. De algunas de estas tropas auxiliares conocemos sus nombres: el ala I Pannoniorum, la cohors IV Commagenorum, una cohors II Ha[miorum?], y otras alas o cohortes «Flaviae» de identificación menos segura ${ }^{56}$.

55 Y. Le Bohec, Troisième Légion Auguste, p. 372.

56 Y. Le Bohec, «Les auxiliaires de lal IIle Légion Auguste», B.C.T.H., 1976-1978, 109-122. La problemática de la identificación de la unidades no se ha resuelto del todo, pero sí se ha hecho una lectura segura de los fragmentos inscritos que nos han llegado del monumento (y discurso) de Hadriano. De nuevo remito, ineludiblemente, a la monografía Y. Le Bohec (ed.), Les discours d'Hadrien à l'armée d'Afrique. Exercitatio, Paris 2003, en particular las páginas 79-114, donde han trabajado en equipo J.F. Berthet, J.-M. Lassère, Y. Le Bohec, y C. Wolff. El texto 1 contiene la dedicación del monumento. El texto 2 contiene el preámbulo del discurso a los legionarios, y la fecha. Los textos 3 y 4 , las palabras del emperador a la infantería legionaria. Y éste último el inicio de las palabras para la caballería de la legión. El n. ${ }^{\circ} 5$ para una unidad mixta desconocida de tropas auxiliares. El n. ${ }^{\circ} 6$ las palabras dirigidas a los jinetes del ala I de los Panonios; que concluye en el fragmento 7, que es también donde se inicia el discurso a los infantes de la cohorte VI de los Comagenos. El texto 8, muy deteriorado, pues apenas quedan unas palabras sueltas, no permite siquiera saber a qué unidad iba dirigido el discurso, aunque $\mathrm{C}$. Wolff propone aquí que se trata de la cohors II H[amiorum] ? (ver págs. 95-97 para la discusión). Otro tanto podemos decir del fragmento 9, mucho mayor que el anterior, pero del que tampoco podemos conocer el cuerpo de tropa destinatario, aunque indudablemente se trata de auxilia. Bajo la signatura $\S 10$ se recogen textos fragmentarios de distinto interés y extensión, siendo con diferencia el más importante el 10.1.1, que una hace alusión, bastante compleja de interpretar, al signum. A continuación se serian multitud de pequeños fragmentos, inconexos entre sí, y en los que se ha hecho un gran esfuerzo de interpretación epigráfica y de contextualización. Precisamente para el contexto histórico sigue siendo muy valiosa la aportación de A. Birley, Adriano, Barcelona 2003, 262-275 (tradución al español, ipor fin!, de la mejor biografía que se ha escrito hasta el momento de este emperador, sobre el original publicado en Londres en 1997). 
Así pues, el elemento humano estaba constituido por ciudadanos romanos de la legión III; dos escuadrones de jinetes panonios -y otro escuadrón del que no conocemos su nacionalidad-, y al menos tres batallones de infantería, entre los cuales uno es de comagenos (en el Asia Menor anatólica), y otra de sirios de $\mathrm{He}$ mesa (Oms). También puede sugerirse la presencia de un cuerpo de caballería cántabra o jinetes cántabros integrados en otras unidades ${ }^{57}$.

Aquellos hombres rudos de las montañas del norte de Hispania mostraban orgullosos al emperador Hadriano, en este escenario o en otros, sus antiguas tácticas de combate, que podían ser consideradas «bárbaras ${ }^{58}$ ", pero que habían sido integradas (hombres y tácticas) en el ejército romano con toda naturalidad, como un cuerpo «especializado». Y así se mostraron ante su general en jefe en Lambaesis, la guarnición de la legión III Augusta que, desplegándose, guardaba para Roma la frontera africana a las puertas del gran desierto del Sahara. Fue en época antonina cuando el ejército romano se enriqueció con aportes humanos completamente nuevos que acrecentaron su potencial numérico, pero también multiplicó las etnias, los tipos de armamento y las técnicas de combate, que, en general fueron respetadas (o aprovechadas) por los generales romanos. Es el mismo Hadriano el que, según nos recuerda Arriano, estableció que se debían ser respetadas los métodos de combate y las armas propias, «nacionales», que traían los armenios, partos, sármatas o celtas que se incorporaban a los ejércitos de Roma.

Estos son los ejercidos que los jinetes romanos han practicado desde antiguo. Ha sido idea del emperador [Hadriano] el que también se ejerciten en los usos de los bárbaros, tal y como se entrenan los arqueros a caballo de los partos y de los armenios, así como las evoluciones de los expertos lanceros sármatas y celtas, que mueven sus caballos hacia el ataque o bien apartando sus corceles. También aprenden los distintos modos de lanzamiento que éstos usan en la guerra y son útiles para combatir; así como la forma de lanzar los gritos de guerra que son propios de cada nación: es decir clamores célticos para los jinetes recibidos celtas, géticos

57 Era famosa la maniobra de caballería conocida como «cantabricus impetus», consistente en una marcha o giro violento de los jinetes, que en un determinado momento cambiaban a la derecha, cubriendose con los escudos mientras lanzaban sus armas contra el enemigo. Sobre esta maniobra táctica: R. Lión Valderrábano, El caballo y su origen. Introducción a la Historia de la Caballería, Santander 1970, 230231. J. González Echegaray, Cantabria a través de su historia, Santander 1977, 73-74. Eiusd., Los cántabros,Madrid 1986, $2 .^{\circ}$ edic., p. 166. El giro de los caballos «a la derecha» estaba encabezado, dirigido o indicado por un hombre que daba la voz, el dextrator, que es el que da voz en alto la orden: - «Ad dextram!». Para comprender en qué consistía la misma, es fundamental la noticia que nos da Flavio Arriano, Táctica, 40, 1-12. Arriano dice textualmente epelasis (=impetus); y kiklos (=circulus).

58 La escasa romanización de este pueblo hace que en su equipo militar se conserven armas propias (de tipo céltico), así como determinada forma de montar los caballos. En la región de Asturias y de Cantabria existían buenos rebaños de caballos, de escasa altura, pero fuertes. La abundancia de caballos en la región explica la proliferación de alae asturum y de las cohortes cantabrorum (equitatae?). El armamento «de tipo céltico» o «ibérico» de los soldados cántabros se ha conservado en algunas monedas, donde aparecen montados a caballo. A.M. de Guadán, Las armas en la moneda ibérica, Madrid 1979, 7677, da las siguientes imágenes: denario ibérico de la ceca de Arsaos (jinete blandiendo un arma), denario (dos tipos) de Emerita Augusta acuñadas por Carisio con motivo de las guerras cántabras, donde se representan distintas armas cántabras: caetra (escudo redondo), un puñal de antenas, y soliferrum. Sobre estas acuñaciones de Carisio, ver ahora: N. Santos Yanguas, «Las acuñaciones monetales de Publio Carisio, legado de Augusto en Lusitania, y la conquista romana del N. O. peninsular», Aquila Legionis 4, 2003, 165187. 
para los getas, réticos para los de Recia. Además aprenden sus cabalgaduras a saltar las cercas y las fosas. En una palabra, no hay entre los romanos algún ejercicio antiguo o en desuso, en el que no se ejerciten de nuevo y con renovado interés. Y del mismo modo se ejercitan [los jinetes romanos], según deseo del emperador, en la rapidez y en la eficacia de las guerras... ${ }^{59}$.

La aceptación y promoción de este tipo de tácticas «bárbaras» que Hadriano practicó durante 20 años de buen gobierno ${ }^{60}$ no son sino la continuación de la política de integración étnica y táctica emprendida por el gran Trajano, que sumó a sus ejército unidades ligeras de Mauri, aquellos bereberes cuya intervención fue tan importante en las guerras de Trajano, y lo mismo podemos decir de los equites saggitari, arqueros a caballo que imitaban a las tropas de los arsácidas ${ }^{61}$, o de los jinetes y caballos catafractarios, representados en la columna Trajana, con su impresionante equipamiento de cota de malla ${ }^{62}$.

Así pues, en Lambaesis el emperador inspeccionó las tropas, las instalaciones, y les habló como lo hace un buen general, con atención e interés, dando consejos, y enfatizando los valores de la vida militar ${ }^{63}$, para dar a entender que sabía más que todos ellos, aunque fuesen tácticas aprendidas en un gabinete, tras horas de estudio de obras de teoría militar como la que había escrito su amigo Flavio Arriano, ese «nuevo Jenofonte» 64 .

Sirva este ejemplo para ilustrar una realidad: cómo las tradiciones y la patria originaria del soldado no se pierden nunca en el ejército, pero a la vez son superadas por otra categoría jurídica y profesional de mayor fuste: ser soldado de Roma, es decir, aceptar el estatuto militar, atender a su disciplina y obedecer a sus oficiales y generales. Los soldados de un mismo campamento son compañeros de armas, de fatigas, de largas marchas, sobrevivientes de batallas y tienen en mente comunes destinos a corto plazo y a largo. Compañeros de armas, y en la vida cotidiana $^{65}$ compañeros de la vida misma, que viven en su campamento (si es que es estable) o en su unidad como en una ciudad organizada conforme a los cánones especiales de la disciplina militar y a sus leyes internas no siempre escritas.

La siguiente tabla, tomada del libro de Le Bohec sobre la legión III Augusta ${ }^{66}$, tan rica en documentación epigráfica, nos ilustra perfectamente sobre la proce-

59 Táctica, 44. Traducción mía.

60 Como dice el mismo Arriano en el punto final del mismo capítulo 44 de la Táctica.

61 G. Brizzi, Il guerriero, l'oplita, il legionario. Gli esserciti nel mondo classico, Bologna 2002, 178.

62 Muy bien descritos por Heliodoro en su novela Etiópicas IX, 15.

63 J.-L. Voisin, «Au miroir des discours d'Hadrien: hommes et valeurs militaires», en Y. Le Bohec (ed.), Les discours d'Hadrien, 21-40.

64 Ph. A. Stadter, «Flavius Arrianus: The New Xenophon», G.R.B.S. 8, 1967, 155-161.

65 Sobre la vida cotidiana del soldado romano en el Alto Imperio hay trabajos muy interesantes, entre los que destaco los siguientes: G.R. Watson, The Roman Soldier, London 1960. R.W. Davies, «The Daily Life of the Roman Soldier», ANRW, II,1, Berlin/NY 1974, 299-388. Imprescindible es el hermoso libro que reúne los principales trabajos de R. Davies, Service in the Roman Army (edited by David Breeze and Valerie Maxfield), Edinburgh 1989; y el estudio muy sugerente y bien escrito de J.M. Carrié, «El soldado romano», en A. Giardina (ed.), El hombre romano, Madrid 1991, 121-160.

66 Op. cit. p. 503. 
dencia de los soldados que componían esta legión, desde comienzos del reinado de Hadriano hasta Gordiano III. También permite visualizar el progreso de la incorporación de autóctonos, cuyas cifras se disparan para la época severiana, siendo ésta también la época evaluada que registra un aumento espectacular de reclutamiento de soldados legionarios con origo castris.

\begin{tabular}{|c|c|c|c|c|c|c|c|c|c|}
\hline Años & Total & $\begin{array}{c}\text { Extran- } \\
\text { jeros }\end{array}$ & $\begin{array}{c}\text { Africa- } \\
\text { nos }\end{array}$ & $\begin{array}{c}\text { Procon- } \\
\text { sular }\end{array}$ & $\begin{array}{c}\text { Estepa } \\
\text { y límites }\end{array}$ & $\begin{array}{c}\text { Tripoli- } \\
\text { tania }\end{array}$ & $\begin{array}{c}\text { Numidia } \\
\text { Cirtensis }\end{array}$ & $\begin{array}{c}\text { Numidia } \\
\text { militar }\end{array}$ & castris \\
\hline $117-161$ & 281 & 115 & 166 & 68 & 36 & 7 & 7 & 8 & 40 \\
\hline $161-192$ & 65 & 3 & 62 & 24 & 12 & 1 & 6 & 5 & 13 \\
\hline $193-238$ & 524 & 24 & 501 & 120 & 83 & 6 & 56 & 48 & 188 \\
\hline Total & 872 & 143 & 729 & 213 & 131 & 14 & 69 & 61 & 241 \\
\hline
\end{tabular}

Todos estos datos, pues, corroboran la idea de que el ejército romano — del que aquí se toma como paradigma la legión III Augusta - es una institución plurinacional sin dejar de ser por ello plenamente romana.

\section{2.c) Una manifestación religiosa común (y no excluyente) para los militares de todas las etnias: los dii militares y el culto imperial}

He hablado de distintos pueblos, de distintas etnias, de diferentes unidades y de distintos grupos sociales. También me he referido a los dioses «patrios» que los soldados traían en "sus mochilas", en sus profundos e inescrutables sentimientos religiosos que podían, o no, aflorar en dedicaciones que se sustanciaban generalmente con una inscripción sobre piedra.

Naturalmente yo no voy aquí a hablar del culto imperial, puesto que otros lo han hecho antes con más autoridad y detenimiento ${ }^{67}$, si bien hay que reconocer que no siempre se ha incidido suficientemente en el papel difusor del ejército en la práctica y promoción de tal culto. La misma religio militaris está pendiente de un estudio definitivo de conjunto ${ }^{68}$. Yo sólo quiero insistir ahora en el hecho de que el

67 Por ejemplo, para la Península lbérica, el libro clásico de R. Étienne, Le culte imperial dans la Péninsule Ibérique d'Auguste à Dioclétien, Paris 1958 (reimpresión de 1974); y más recientemente, con mayor ámbito espacial y mayor profusión de datos, abarcando todo el imperio, la obra en varios volúmenes de D. Fishwick, The Imperial cult in the Latin West: Studies in the ruler cult of the western provinces of the Roman Empire, Leiden, 1987 ss.

68 A. von Domaszewski, «Die Religion des römischen Heere2, Westdeutsche Zeitschrift für Geschichte und Kunst 14, Trier (1895) 1-128. Reeditada en Aufsätze zur römischen Heeresgeschichte, Darmstadt, 1972. El espíritu de esta obra fue recuperado, y actualizado en la documentación, en la tesis doctoral de H. Ankersdorfer, Studien zur Religion des römischen Heeres von Augustus bis Diokletian, 1973, Konstanz. Sendos status quaestionis, con bibliografía temática, pueden verse en los estudios de $\mathrm{E}$. Birley, «The Religion of the Roman Army: 1895-1977», ANRW II, 16.2, 1507-1541, y el de H. Helgeland, «Roman Army Religion», ANRW II, 16.2, 1471-1505. El intento de M. a J. Moreno Pablos de documentar la religión del ejército romano en Hispania (en su libro La religión del ejército romano: Hispania en los siglos I-III. Madrid 2001, cfr. mis reseñas en Gerión 19, 2001, 825-826, y en Ilu, Revista de Ciencias de las Religiones 6, 2001, 313-314.) es fallido. Omito deliberadamente muchos artículos cortos sobre la religión 
soldado, que concebía su vida, para conservarla, estando siempre alerta, necesitaba invocar, más que a divinidades abstractas e inaccesibles, a divinidades actuantes, cercanas, operantes, que realmente le ayudaran en su trabajo diario, en su oficio. Y es en este sentido y razón en el que se enmarcan, por una parte, cultos militares exclusivos, el de los dii militares (en general, o bien con nombres y/o apellidos propios) ${ }^{69}$, entre los que destaca el culto al aquila y a los estandartes, así como la devoción a los genii ${ }^{70}$. Los genii militares son muchos y con ámbitos de actuación bien precisos: se honra al genius legionis ${ }^{71}$, al genius castrorum ${ }^{72}$, al genius alae / cohortis $^{73}$, al genius vexillationis ${ }^{74}$, al genius turmae ${ }^{75}$, al genius nu$m^{2} i^{76}$, etcétera, y existen, por otra parte, dedicaciones realizadas por militares al genius provinciae ${ }^{77}$, al genius stationis ${ }^{78}$, al genius $10 \mathrm{ci}^{79}$, al genius praetorii ${ }^{80}$, al genius tabularii ${ }^{81} \mathrm{u}$ otras dependencias ${ }^{82}$.

del ejército romano que tratan aspectos parciales. Para Hispania, ver ahora: G. Andrés Hurtado, Una aproximación a la religión del ejército romano imperial: Hispania, Logroño 2005.

$69 \mathrm{Me}$ refiero a dioses que en la milicia toman un rol especial o a dioses oficiales tópicos a los que se añade un epíteto militar, por ejemplo, Mars Campester.

70 M.P. Speidel, A. Dimitrova-Milceva, «The cult of the Genii in the Roman Army and a New Military Deity", ANRW II, 16.2, 1542-1555.

71 Vid. Domaszewski, op. cit., 66, 96, 114; Ankersdorfer , opt. cit., 196-200. La dedicación más antigua al genio de una unidad militar se data en los últimos años del siglo I, procede de Vindonissa (Germania superior), vid. AE 1926, 69; Speidel Dimitrova, op. cit., 1545: > (centuria) Domoti(i) ...TODI, Val(erius) Tertius, Genio leg(ionis) XI C(laudiae) p(iae) f(idelis) pullum (dedicavit), v(otum) s(olvit) I(ibens) I(aetus) m(erito). Más textos del Genius legionis en ILS 2290, 2295; AlJ 267; ILAlg.I,2044; RIB 327; RIU 236, 390; AE 1957,83; $A E$ 1968,391; AE 1971,208; $A E$ 1973,471; etc.

${ }_{72}$ CIL VI 230,231, 36775-36777; CIL XIV 7, ILS 2216, 2215, 484, 9080, 2217; CIL VIII 2529=ILS 2291; AE 1963,45; AE 1962,391. Véase: Domaszewski, op. cit., 35 y 113; Ankersdorfer, op. cit., 200-201.

${ }_{73}$ Por ej., CIL III 1356, Genius cohortis II Flavia Com(m)agen(orum); y AE 1958,240 (=A. Mariq, "Les dernières années de Hatra», Syria 34 (1957), 289). Vid. Domaszewski, op. cit., 51, 96, 96, y Ankersdorfer, op. cit., 202 ss.

74 L. Cesano, «Genius»», Diz.Ep. III (1922), 475 ss. Añadir CIL XIII 7943. Ankersdorfer, op. cit., 205.

75 Domaszewski, op. cit., 107; Ankersdorfer, op. cit., 214.

76 CIL XIII 6600, 6642, 7751; y avanzado el siglo III, Genius n(umeri) Maur[o]rum Aur(elianorum) Valeriani Gallieniq(ue), (RIB 2042 Aballava, Burgh-by-Sands, en Britania). Ver: Domaszewski, op. cit., 96, Ankersdorfer, op. cit., 202-205.

77 En Aquincum se rinde culto al Genius provinciae Pannoniae y a la Fortuna huius loci (CIL III 10396, 10399, de Valerius Pudens, año 194); G. Alföldy, "Geschischte des Religiösen Lebens in Aquincum», Acta Arch.Hung. 13, 1961, 111 y 115. Sobre e culto al Genio en Dacia: A. Bodor, "Die Griechichs-romischen Kulte in Dacia", ANRW II, 18.2 (1989), 1132 y n.386

${ }_{78}$ CIL III 8173; CIL VI 36779; CIL VIII 17623, 17625, 17626; CIL XII 144, CIL XIII 6127

79 Dedicación a Genius stationis speculatorum: D. Tudor, Olténia romana, Bucarest 1958², 422 n. ${ }^{\circ}$ 300 = AE 1959,330: I.O.M. Dia]nae Sanc/[ta]e Mercurio G[u]/bernatori e[t Genio] / stationis A[el? Ger]/manus spe[cul(ator) leg(ionis)] / VII Cl(audiae) [- . - . - - / pr(idie) n(onas) S(eptembrium) An(tonino) / [et Advento co(n)s(ulibus)] (año 211). Numerosísimas son las de dedicaciones de los beneficiarii al Genius estationis / loci, véase ahora CBFIR p. 822 índice.

80 En Lambaesis, M. Le Glay, «La vie religieuse a Lambèse d'après de nouveaux documents", Antiquités Africaines 5, 1971, 137: Genio / praetori(i) / sacrum. En Hispania: CIL II 4076=ILS 2297=RIT 34; y CIL II 2634=ILS 2299 .

${ }_{81}$ CIL VI 30886; CIL XIII 7752; CIL VIII 18060; EE V 711; J.-P. Waltzing, Étude historique sur les corporations profesionelles chez les romains depuis les origines jusqu'a la chute de l'empire d'Occident, [Louvain 1895-1900], Roma: L'Erma 1968, n. 1446 ; ILS 2447: Genio / tabul(arii) princ(ipis) / Mine/rvae Augus(tae).

82 Ver más referencias en Speidel - Dimitrova, op. cit., 1549 n.27; para el Genius armamentarii (sc. leg.I Italicae en Novae), ibid. 1551-1553. 
Si entendemos a estos genii como numina actuantes, en la más clásica y antigua tradición romana de los indigitamenta, se entiende muy bien el por qué los soldados rinden culto al Genius Imperatoris. El emperador es para ellos, más que un dios viviente, una fuerza actuante a través de su genius. El genius que otorga al emperador reinante el carisma de general en jefe. Y por eso se le sitúa «entre los dioses» o a su lado "como un dios». Sirva como ejemplo este hermoso documento, un altar procedente de High Rochester (Bremenium) ${ }^{83}$ en Britania, donde se lee:
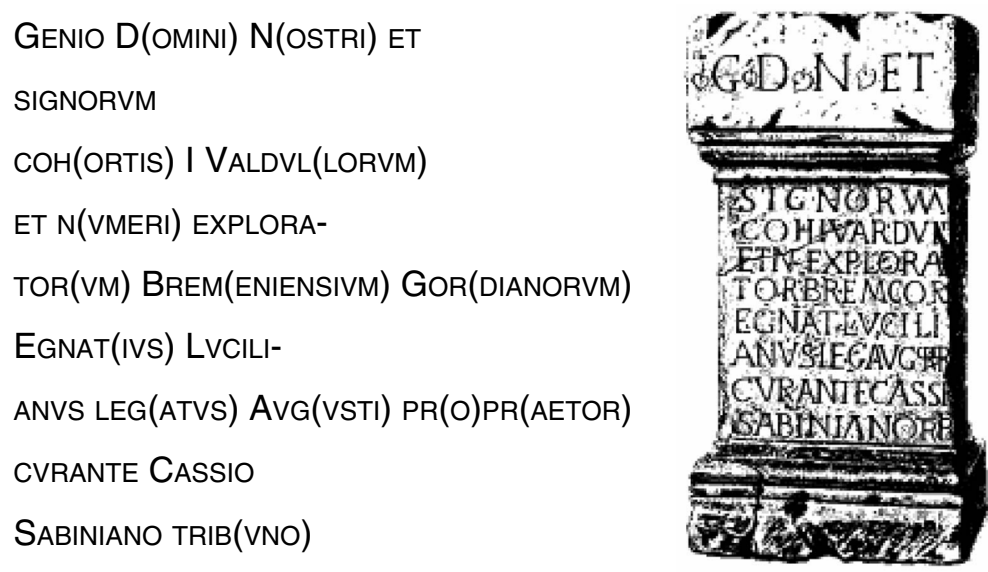

Vemos en el encabezado, en siglas, la invocación al «Genio de Nuestro Señor» (el emperador Gordiano), y también a los signa, a los estandartes de la unidad que hace el voto, la cohorte primera de los Várdulos (hispanos), asociada a las tropas de «irregulares» (numeri) de Bremenium, reclutados en el lugar, que conocían muy bien la topografía y por eso hacían de exploradores. Hispanos y britanos, pues, invocan a los mismos dioses o numina. Pero no es ésta la única alianza o comunión religiosa (en horizontal en el plano profesional) sino que tal simbiosis también se produce en vertical, pues los oficiales militares, el tribuno Cassius Sabinianus que manda a estos auxilia, y aún por encima de él el mismo legado imperial, se unen en un acto religioso verdaderamente memorable ${ }^{84}$. Mandos de distintos rangos, y tropas de distinta nacionalidad y funciones, elevan su plegaria y depositan su confianza (no me atrevo a decir su fe, aunque en toda alianza hay un pacto de fidelitas, expresada o tácita) en el Genio del Emperador y en el estandarte que sale a combatir con ellos.

El estandarte con las imagines imperiales es una réplica o doble del estandarte que exhibe el aquila sancta de la legión, pero son dos estandartes distintos y con distinta significación. Para mí, el del aquila tenía más autoridad religiosa, el signum

${ }^{83}$ RIB 1262. De época de Gordiano, obviamente, por el apelativo de la unidad, fiel a este emperador en los acontecimientos de 238.

${ }^{84}$ Memorable no en el sentido de excepcional por la intención de perpetuarlo en la memoria mediante la erección de este altar. 
con la imago imperatoris más autoridad o significado político. El águila de una legión podía y debía sobrevivir a muchos emperadores.

Pero también las piedras inscritas — como ésta que he comentado-con los testimonios de devoción por parte de los soldados al emperador han quedado enhiestas siglos y siglos como testimonios inertes (pero a la vez vivos) de un común sentimiento de todos los soldados del Imperio hacia el Dominus que desde el trono de Roma o desde la silla de su caballo rige sus destinos, porque los soldados son parte y se sienten involucrados en el destino de Imperium Romanum.

\section{2.d) La lengua}

La lengua, el latín, es un hecho cultural (y práctico) de primer orden para que el soldado romano no se sintiese extranjero, fuese cual fuese la lengua paterna y donde quiera que estuviese su lugar de nacimiento.

Todos los soldados - en mayor proporción y medida en el Occidente romano que en la pars Orientis - entendían el latín, y se debían hacer entender en la misma lengua, conocer las consignas de maniobra y de marcha, entender las órdenes de sus superiores, y saber leer (aunque esto de hecho no sucedía siempre) los partes del día, la minuta de su paga o las inscripciones públicas (un pedestal de estatua de un legado, por ejemplo, o una dedicación a una divinidad). Es posible que en la privacidad de los barracones, los soldados del mismo origen hablasen en la lengua de su infancia, y que siguieran creyendo en los beneficios de adorar a un dios patrio de enigmático nombre para los demás (incluso también para ellos mismos) ${ }^{85}$, aunque indudablemente, traspasada hacia fuera la puerta de la tienda de campaña o del barracón de madera había que «incorporarse» naturalmente al uso de latín y adorar «también» a otras divinidades romanas «oficiales». A veces se «compaginaban» en la minuta epigráfica y en la inscripción dioses romanos y dioses patrios o indígenas. Estos dioses no romanos ¿son «patrios» de la natio o lugar de nacimiento del soldado o «patrios» en el sentido de «locales», allí donde se asienta la unidad y donde se levanta la inscripción? Una vez más, cautela.

Pero no entremos ahora en la evidencia de los cultos probables, y volvamos a la importancia del uso de una lengua común como agente disolvente de conceptos como «barbarie» = «extranjeridad» como sinónimo de incultura según el antiguo concepto griego. Conviene recordar que «el ejército romano cubría dos

85 Compárese a modo de ejemplo las divinidades indígenas invocadas en inscripciones por los soldados hispanos en el noroeste peninsular, en P. Le Roux, «Soldats et cultes indigènes dans les provinces occidenrtales au Haut-Empire», Conimbriga 41, 2002, 105-126, donde podemos leer dedicaciones a dioses indígeneas locales, en aras votivas, a Bandu(a) Veigebraecus, a deus Turiacus, a Trebarun(a), a Ataecina, o a Moelius Mordoniegus, siendo los dedicantes de distintos orígenes y sirviendo en unidades muy dintas: la cohors I Gallica c.R., la coh. III Lusitanorum, el ala Vettonum, o las legiones VI Victrix o VII Gemina. 
áreas lingüísticas muy diferentes, el Occidente latinófono y el Oriente helenófono, donde el latín se había impuesto como idioma oficial militar en los archivos y en papeleos de los campamentos auxiliares y legionarios: bastaba con que los soldados destinados a las escrituras (los signiferi, particularmente) fueran capaces de escribir el latín. Lo cual no excluye que ciertos soldados de origen oriental hayan sido capaces de redactar en un latín muy correcto, cargado como mucho de la huella de las interferencias sintácticas y fonéticas del griego que hablaban corrientemente, además de la lengua local. Esta situación ha hecho desempeñar al ejército un papel importante en los intercambios y préstamos del latín al griego, y ha dado al lenguaje militar ciertos aspectos de lenguaje de comunicación internacional.... ${ }^{86}$. Muchos soldados, por tanto, eran bilingües en la comunicación verbal, y no era infrecuente encontrar (sobre todo en Egipto) simples soldados que hablaran del mismo modo griego y latín, como lo prueban algunas cartas de soldados egipcios escritas sobre papiro. Tal es el caso del soldado Apión, el cual, una vez enrolado en el ejército, toma el nombre de Antonis (sc. Antonius) Maximus y escribe a su padre para comunicarle que ha llegado a Italia tras una tempestad. Menciona en sus oraciones a Serapis, y dice que recibió una paga del emperador para el viaje. Aprovecha su estancia en Italia para hacerse un retrato, que promete enviar a su padre, a Egipto ${ }^{87}$.

También había soldados que conocían y leían la Eneida, y otros incluso hacían sus pinitos literarios ${ }^{88}$, como refleja ese «extraño saber» de un grupo de soldados del destacamento africano en el fuerte de Gholaia, actualmente Bu Njem (en Libia), donde un conjunto de ostraca fechados entre 253-25989 muestran cómo un centurión de origen africano, M. Porc. Tasuchtan, se empeñó en igualar a su predecesor Q. Avidio Quintiano en el arte de la poesía escribiendo unos yámbicos senarios de buena calidad. El afán de aprendizaje «escriturario» y, en sentido más amplio «literario» de los soldados era grande, pues en cierta medida su promoción dependía de ello. En el mundo antiguo la escritura es poder. Pasar a las oficinas de administración del campamento o al palacio del legado de la legión o del gobernador provincial dependía de su formación de escribanos. Era la mejor forma de dejar en segundo plano el duro oficio de armas. Se trata, como viene a decir Jean-Michel Carrié, la lucha del soldado por quitarse su estigma de campesino para formarse y alcanzar un «espíritu de urbanitas» ${ }^{90}$.

86 J.M. Carrié, «El soldado romano», (citado antes), 151.

87 G. Milligan, Selections from the Greek Papyri, ed.. Cambridge 1910, $1912^{2}, 1927^{3}$, n. $^{\circ}$ 36. J. Leipoldt / W. Grundmann, El mundo del Nuevo Testamento, II, Madrid 1973, 75 (tr.). El texto es de Fayum, del siglo II d.C. La correspondencia completa entre padre e hijo puede leerse en: E.M. Smallwood, Documents, n. ${ }^{\circ}$ 397. Edito y traduzco el texto completo ahora en: S. Perea Yébenes, «Ejército y vida cotidiana en el Egipto romano en tiempos del emperador Trajano a través de un florilegio de cartas conservadas en papiros griegos y latinos», en prensa.

88 Sobre la cultura/incultura de los legionarios, cf. J.M. Carrié, «El soldado romano», (citado antes), 150-153.

89 Y. Le Bohec, La Troisième Légion Auguste, 546-547.

90 J.M. Carrié, «El soldado romano», (citado antes), 152. 
El latín como lengua militar (sermo militaris) prevalece a todos los niveles. Es la lengua utilizada en los documentos «oficiales» internos, por ejemplo el calendario festivo en Dura Europos ${ }^{91}$, y la lengua en la que se redactan las órdenes y servicios del día en un campamento de Egipto ${ }^{92}$, o los recibos de paga de los soldados. Los diplomas de licencia de soldados auxiliares, que son documentos oficiales, se escribían siempre en latín. Y ésta es la lengua predominante en los comunicados y notas oficiales del fuerte de Vindolanda, situado en la frontera norte del Imperio, en Britania, en el muro Hadriano, y que ha legado una documentación excepcional $^{93}$. Se trata de «una serie de cartas y documentos halladas en un lugar en el que durante los primeros años de ocupación romana (circa 91-102/3 d.C.) se encontraba la residencia (praetorium) del comandante de la unidas o de una de las unidades militares acantonadas en Vindolanda. Tenemos grupos de cartas relacionadas con individuos particulares y grupos de textos relacionados por su índole o tema, lo cual ofrece un álbum de imágenes durante dos décadas o más que revelan a Vindolanda y a sus ocupantes a través de las cartas y escritos conservados en casa del comandante; y esa es una cuestión de los archivos oficiales de la unidad militar" ${ }^{94}$. Los textos son reflejo de la dura vida de los soldados en un fuerte en la frontera norte del Imperio, muy lejos pues de Roma, pero también son reflejo e

91 Enclave estratégico de Siria donde con toda seguridad muchos de los soldados hablaban el griego. Sobre el calendario militar de Dura: J. F. Gilliam, «The Roman Army in Dura», en C.B. Welles, R.O. Fink, J. F. Gilliam, The Excavations at Dura-Europos, Final Report V, Part I: The Parchments \& Papyri, New Haven 1959, 22 ss. = Roman Army Papers, Amsterdam 1986, 211-212. R.O. Fink, A.S. Hoey, W.F. Snyder, «The Feriale Duranum», YCS 7, 1940, 1-122. El texto del FD está preproducido, con notas críticas, en R.O. Fink, Roman Military Records on Papyrus Cleveland 1971, 422-429 n. ${ }^{\circ} 117$, y en J. Helgeland, «Roman Army Religion», ANRW II,16. 1, 1978, 1470-1505. Una valoración general del FD en el contexto de la religiosidad romana en A. D. Nock, «The Roman Army and the Roman religious year», HTR 45, 1952, 186-252 (= Essays on Religion and the Ancient World, II, 1972, 736-790). Nuevos puntos de vista refutando algunas de las opiniones de Nock, pueden leerse en el trabajo de J. F. Gilliam, «The Roman Military Feriale», HTR 47, 1954, 183-196 = Id, Roman Army Papers, Amsterdam 1986, 123-136. Un cuadro-resumen del calendario, con un comentario sobre los dii militares, puede verse en Y. Le Bohec, L'armée romaine, Paris 1989, 258-262. Un comentario de tipo religioso general, M. ${ }^{a} \mathrm{~J}_{\text {. Moreno Pa- }}$ blos, La religión del ejército romano: Hispania en los siglos I-III, Madrid 2001, 55-64. También puede verse mi trabajo, S. Perea Yébenes, «Heliogábalo, Severo Alejandro y la fiesta de Vesta en el calendario militar de Dura Europos», con un apéndice donde doy una edición canónica en latín del calendario y una versión española, en mi libro Entre Oriente y Occidente. Temas de Historia romana: aspectos religiosos, Madrid 2002, 345-366.

92 R.O. Fink, «Hunt's Pridianum», JRS 48, 1958, 102-116 (cfr. JRS 49, 1959, 26-33). E.M. Smallwood, Documents, n. ${ }^{\circ} 302$.

${ }_{93}$ Sobre estos documentos, remito, obviamente, a la edición de los mismos, en varios volúmenes, debidos a A.K. Bowman: Roman Writing-Tablets from Vindolanda. London 1981. Id., Life and letters on the Roman frontier. Vindolanda and its people. London 1994. A.K.Bowman, J.D.Thomas Vindolanda: the Latin writing-tablets. Britannia Monograph 4. London 1983. Sobre el fuerte-campamento y la exploración arqueológica: R.E.Birley, Vindolanda. A Roman frontier post on Hadrian's Wall. London 1977. Id., The Roman documents from Vindolanda. Newcastle upon Tyne 1990. Especialmente interesante resulta el análisis general sobre la importancia del latín y la comunicación escrita en esta guarnición militar, en el estudio de A.K. Bowman, «El ejército imperial romano: las cartas y la cultura escrita en la frontera septentrional», en A. K. Bowman, G. D. Woolf, Cultura escrita y poder en el Mundo Antiguo. Barcelona 2000, 173-197 y 355-357 (con la bibliografía relativa a Vindolanda).

94 A.K. Bowman, «El ejército imperial romano: las cartas y la cultura escrita en la frontera septentrional», 173-174. 
ilustración de la educación del soldado, y de su interés por organizar su vida en comunidad, donde en efecto, «la alfabetización, la burocracia y la documentación fortalecen la autonomía de la institución en que se dan»" ${ }^{95}$, como, en ese caso, el ejército, el cual tiene notorio afán de registrar por escrito todas las operaciones administrativas y militares. El latín como lengua militar se presenta como instrumento unificador e integrador en el aparato administrativo romano, al cual podría acceder aquellos soldados capaces e interesados en dominar la lengua del Lacio a nivel escrito (litterati), y aspirar a un ascenso, cualquiera que fuese la patria o la lengua primera del soldado.

Además de las indicadas, son muchas más las aportaciones que el ejército hizo en favor del Imperio, y que, consciente o inconscientemente, tendieron a extender su cultura y una conciencia multi-étnica en sus territorios, pues los contactos de los militares y del ejército con la población civil afectó a muchos ámbitos y fenómenos humanos importantes, como son los movimientos migratorios, la economía que genera el ejército, las innovaciones técnicas, la ingeniería militar aplicada a las obras públicas de las ciudades, el ejército como factor regulador de la población (acelerador al mismo tiempo de la natalidad y causante de muchas muertes), el factor romanizador de poblaciones marginales y del agro, la vida religiosa y asociativa, etcétera.

Aquí he tratado diversos aspectos de la milicia aparentemente dispersos, aunque realmente, muy al contrario, todos ellos son buenos exponentes de integración de grupos humanos y de tolerancia inter-étnica y intercultural, y me han servido al objetivo de mostrar que en el ejército romano del Alto Imperio había una extraordinaria mezcla de razas, lenguas, religiones y estatutos personales, que sólo esta institución podía reunir en cualquier momento de la época imperial y en cualquier lugar de su extensa geografía, y, es más, podía hacerla funcionar como una verdadera comunidad, y hacerlo del mismo modo en cualquier parte del Imperio.

Esta última frase, enfatizada adrede, significa que tales hechos son eso, hechos, y no circunstancias, y que la tolerancia y la convivencia de los soldados en los aspectos indicados (tan importantes para toda persona y toda sociedad civilizada) no eran coyunturales, sino estructurales, y que, en su conjunto, otorga al ejército una envidiable entidad como "comunidad», siendo, además, a nivel humano, la mayor Institución del Estado romano, y la única capaz de reunir a tanta gente de toda raza, creencia o lengua bajo una misma disciplina y bajo un mismo cielo.

Con independencia de su estatuto jurídico personal específico, la patria del soldado puede ser una «distinta» en cada momento de su carrera, aunque la principal

95 A.K. Bowman, «El ejército imperial romano: las cartas y la cultura escrita en la frontera septentrional», 185. 
es siempre la propia communitas militaris; del mismo modo que su nación política, su Estado, es el Imperium Romanum. Es un Imperio en el doble sentido etimológico del término, que se refiere tanto a la idea de «mando o poder fáctico» como al territorio en el que tal poder se ejerce. El soldado era agente, protagonista y partícipe de ese Imperio Romano, percibido en lo abstracto y en lo concreto como una entidad superior que prevalece sobre las «patrias» menores, distintas o subsidiarias, originarias o adaptadas, de cualquier soldado $\mathrm{u}$ oficial. 